OBETS. Revista de Ciencias Sociales

Vol. 16, no 2, 2021, pp. 281-296

ISSN: 1989-1385

https://doi.org/10.14198/OBETS2021.16.2.04

\title{
A DISCURSIVE APPROACH TO BULLYING FROM THE PERSPECTIVE OF SOCIAL WORK
} UNA APROXIMACIÓN DISCURSIVA DESDE EL TRABAJO SOCIAL SOBRE EL ACOSO ESCOLAR

\author{
Laura Domínguez de la Rosa \\ Universidad de Málaga, España \\ ldominguez@uma.es \\ https://orcid.org/0000-0002-2172-6383
}

\author{
Mario Millán-Franco \\ Universidad de Málaga, España \\ mmillan@uma.es \\ https://orcid.org/0000-0002-5536-7139
}

Cómo citar / Citation: Domínguez de la Rosa, L. y Millán-Franco, M. (2021) "A discursive approach to bullying from the perspective of Social Work". OBETS. Revista de Ciencias Sociales, 16(2): 281-296. https://doi.org/10.14198/OBETS2021.16.2.04

(C) 2021 Laura Domínguez de la Rosa, Mario Millán-Franco

Este es un artículo de acceso abierto distribuido bajo los términos de la licencia de uso y distribución Creative Commons Reconocimiento 4.0 Internacional (CC BY 4.0) https://creativecommons.org/licenses/by/4.0/deed.es

Recibido: 11/02/20. Aceptado: 31/12/20

\begin{abstract}
The objective of this study was to explore the social framework of bullying using the discourse of the different agents involved. A qualitative method was used (i.e. thematic analysis). We collected information from 25 semi-structured interviews. Four themes were identified: "Descriptive elements of bullying"; "Bullying is a social issue"; "Normalizing bullying hidden behind other types of violence", and "An integrated struggle against bullying". This study shows that bullying is a social problem associated with other types of violence. Bullying should also be studied from the perspective of Social Work to generate new strategies and effective social intervention and prevention programs.
\end{abstract}

Keywords: Bullying; Social Work; Qualitative method; Thematic analysis.

\section{Resumen}

Este estudio tiene como objetivo conocer cómo se está conformando socialmente el fenómeno del acoso escolar a partir del discurso de distintos agentes implicados. Se empleó un método cualitativo, concretamente, el análisis temático. De este modo, para la recogida de la información se realizaron 25 entrevistas semiestructuradas. Se identificaron 4 bloques temáticos que nos ayudan a describir este hecho: "Elementos descriptores del acoso escolar", "El acoso escolar es un problema de la sociedad", "La naturalización del acoso escolar enmascarado en otros tipos de violencia" y "La lucha integral contra el acoso escolar".

Este estudio muestra que el acoso escolar es un problema social asociado a otros tipos de violencia. El bullying también debe ser estudiado desde la perspectiva del Trabajo Social para generar nuevas estrategias y programas de intervención y prevención social efectivos.

Palabras Claves: Acoso escolar; Trabajo Social; Método cualitativo; Análisis temático. 


\section{INTRODUCTION}

School bullying is considered to be a problematic social phenomenon and one of the most frequent forms of school violence. In the English language, "bullying" is a consensus term used to refer to a particular type of abuse in schools. However, this is not the case in the Spanish language, in which different terms, such as intimidación, hostigamiento, "bullying", and maltrato entre iguales are used interchangeably to refer to this particular type of violence. This lack of a single "translation" for "bullying" has created some debate among Spanish researchers. According to Ovejero (2013), all the Spanish terms may be used, but none fully capture some of the behaviors involved in this specific type of aggression. To resolve such debate, some Spanish researchers have opted to use the English term "bullying".

According to Castillo (2011), the term bullying does not include many of the hostile behaviors and attitudes encouraged in schools by social agents such as teachers, parents, and administrative staff. Therefore, it is relevant to establish that not all cases of "school violence" can be classified as bullying. In fact, violent behavior can occur as isolated incidents and would be viewed as a confrontation between two people.

Hymel and Swearer (2015) define bullying as interpersonal aggression characterized by intentionality, repetition, and a power imbalance. Thus, students become victims of bullying when they experience repeated aggressive actions over a long period on the part of one or more students in a situation of power imbalance (Olweus, 1998). Although this classic definition has found widespread acceptance in the scientific community, authors such as Finkelhor, Tumer, and Hamby (2012) have argued that this definition has some limitations. Ayala-Carrillo (2015) has suggested that school violence and bullying should be understood from different standpoints, such as those of the victims, aggressors, and witnesses. This approach should also include peer interactions and problems, family, cultural, and institutional settings, and the consequences and effects of peer abuse on society.

Some authors have proposed that bullying is based on its normalization and ubiquity in the daily life of families and institutions (Gallego, Agudelo, Vásquez, Restrepo and Gálvez,2019). The concept of violence changes as the society and culture in which it takes place evolve. Similarly, the concept of bullying now incorporates threatening behavior and new forms of verbal, social, gestural, and symbolic aggression or intimidation associated with current society (AyalaCarrillo,2015).

In general, current definitions of bullying do not capture the diversity of such behavior found in many situations. Nevertheless, there is a consensus that bullying is a form of physical or verbal aggression that includes, as core elements, a real or perceived power imbalance and aggressive behavior repeated over time (Méndez and Cerezo,2018).

Despite bullying being an old and cross-cultural phenomenon, it was not until the beginning of the 21st century that bullying stimulated real interest in terms of research, intervention, and the implementation of policies at national and international levels (Espelage and Swearer,2004; Nocito,2017). Initial studies tried to provide a definition and conceptualization of school bullying (Ronald,2010). Their main focus was to develop proposals, programs, and strategies to reduce bullying (Ortega,2010).

From 2000 onwards, the main aims of research were to determine the frequency of bullying in schools and to understand the different types of aggressive behaviors involved (Ortega,2010). Other studies compared the incidence of bullying at different educational levels. Research became increasingly specialized around certain issues and variables that provided new interpretations of the phenomenon. The most widely studied variables include sex, age, gender, family, and cultural and educational background. Studies have provided relevant information on age differences in bullying and the most frequent types of bullying (Carrillo,2018; Prieto, Jiménez and Carillo,2010). Such multiple lines of research from different countries have helped determine the nature of bullying, risk factors, consequences, and approaches to prevention and intervention.

Currently, there is an increasing research comparing the prevalence of traditional bullying and cyber bullying (Herrera, Romera and Ortega,2018). Cyberbullying can be considered the new variant of bullying, but in the context of social networks. The main difference between both kinds of bullying is that the Internet 
is used as a means to send violent and intimidating messages. Therefore, there is no direct contact between bullies and the bullied people (Alvites,2019). New technologies and social media have become the axis of human relations. This technological development has made easier for young people to continue to abuse other people and has caused the appearance of new types of violence through electronic resources. Among those, grooming and texting stand out. Grooming is understood as sexual harassment by an adult who poses as a child to establish contact with minors through the Internet. Sexting refers mainly to communications with sexual content that include both text messages and images sent through mobile phones or other electronic devices (Machimbarrena et. al,2018).

Solid research on cyberbullying has provided a relevant body of descriptive knowledge on this phenomenon. However, the use of quantitative methods has some limitations. A quantitative approach tends to leave aside some of the factors involved in violence issues, particularly because of the speed at which social and technological changes are taking place in current society. For example, some mechanisms, processes, and physical and psychic repercussions cannot be studied by determining the frequency, duration, or number of hostile acts (Pulido, Montalbán, Palomo and Luque,2008). Similarly, quantitative research cannot provide information on the appraisal people make of having experienced bullying. Therefore, the current instruments used to assess bullying may not be able to assess certain behaviors that are considered to be bullying behavior from the point of view of the victims.

Despite the wealth of quantitative research, bullying continues to be a recurring problematic behavior that is difficult to identify and solve. In fact, the results of quantitative research on bullying are not often used to guide governmental policies and programs developed to deal with this phenomenon. Qualitative studies on bullying are less common. Most of this research shows the complexity of the contextual aspects and the particularities that violence adopts according to the discourses of the adolescents or the participants themselves (Gallego and Rodríguez,2019; Gómez,2013; Pulido and Tarancón,2018; Smit,2018). In general, these are research studies that look at strengths and capacities from the different roles of the participants (Arias 2015; Zynch, Beltrán, Ortega and
Llorent,2018). However, they lack information about the functions of witnesses. It is understood that this figure is fundamental because it helps the visibility of this phenomenon through its attitudes and actions (Moreno, Tabullo and Segatore,2019).

In an attempt to cover this gap, our study follows a qualitative approach to address this issue, contributing to its understanding and deepening in this problem from the voices of other involved agents such as family members, witnesses and professionals. We consider that to gain a more profound understanding of the phenomenon of bullying, we need to identify the sociopolitical, educational and cultural factors involved.

This implies investigating the scenarios, the agents, and the factors that directly and indirectly affect the onset and development of bullying behavior. In order to do this, we need to listen in depth to the different agents involved. That is, we need to know more about the meaning of bullying from the point of view of the bullies, the bullied, and those who witness bullying. We also need to listen to the voices of parents, teachers, classmates, and friends. The information gathered from these sources could be of first-rate importance to interdisciplinary teams conducting social interventions to prevent and mitigate the effect of bullying in schools (Twemlow and Sacco,2012).

Most qualitative studies have been conducted by researchers working within the disciplines of health sciences, psychology, sociology, and law. To date, very few scientific studies on bullying have been conducted from the perspective of social work. Vázquez (2005) has suggested that social work needs to increase its area of research to new fields in order to develop and advance the profession and the training of social workers. From its beginnings, this profession has been closely associated with social change. Therefore, it should not be dependent on research conducted by other disciplines because such dependency could hinder the advancement of knowledge in emerging social issues.

Social work should develop its own identity in the setting of research and provide new ways of approaching current social issues, such as bullying. Furthermore, given that social issues are complex and dynamic, social work needs to establish stronger links between research and specialized professional training (Barahona,2016). Although several scientific fields 
have conducted research into bullying and developed interventions, the contribution from social work also needs to be included within these perspectives.

In this sense, there are few studies that show the role that professionals in general and, specifically, social workers who belong to the Social Services, have in this type of problems, despite the fact that community resources (such as Social Services) play a particularly important role in preventing, eliminating or treating the causes that lead to marginalization. This highlights the need for multidisciplinary and inter-institutional interventions to prevent this type of violence (Samaniego and Bermúdez,2015).

In the last decade, there has been an increase in media and social concern regarding this type of violence in Spain. Postigo, Schoeps, Ordoñez and MontoyaCastilla (2019) have suggested that the fundamental target of any research on bullying should be to develop useful strategies and interventions for its prevention. In order to achieve this aim, we need to define and delimit bullying from a range of perspectives.

Our research question emerges from these theoretical aspects and is defined as "How is the phenomenon of bullying socially constituted from the discourse of the agents involved?" In this study, we attempt to investigate how the phenomenon of bullying has been socially shaped. We examine definitions, causes, consequences, factors, intervention strategies, and prevention measures from the point of view of the agents involved. We conducted discourse analysis on the interview data collected from the agents involved (i.e. victims, family, friends, and professionals involved in interventions) concerning their views on bullying. Our objective was to raise awareness and provide useful information to society in general and public institutions in particular such that this problem can be more effectively managed.

Mateu-Martínez, Piqueras, Rivera-Riquelme, Espada and Orgilés (2014) and Sánchez and Cerezo (2010) stressed the need for an integrated vision of bullying and a multicausal approach to the problem. Using the knowledge acquired from research, and with special attention to the discourse of social workers, we reflect on how the relational social work approach could improve social intervention on bullying. The information obtained in this study is expected to be effective in establishing preventive and intervention programs for this type of violence.

\section{METHOD}

We used inductive thematic analysis as the qualitative phenomenological method in our study. This approach is heir to the concept of "theoretical or purposive sampling" developed in the context of Grounded Theory (Glaser and Strauss,1967). We explored the perspectives of the victims of bullying and the entire scenario in which bullying takes place. This involved listening to the voices of the families and professionals involved. The social reality of bullying is a product of the way participants explain, describe, and experience this phenomenon within their social and cultural settings (Cabruja, Íñiguez and Vázquez,2000). From this first analysis we obtained a set of topics we call "themes". Themes are common lines of argument that proceed from the literal transcription of interviews and that are used to describe and explain reality (Domínguez and Montalbán,2017).

\section{PARTICIPANTS}

The participants have been selected through a deliberate theoretical sampling. And, in order to expand the possibility of interviewing other informants, the snowball sampling strategy was used. Thus, we ensured that the sample included key informants who were involved in research or who played an active role within the social discourse of bullying. The final sample comprised 25 participants. Of these, ten were students involved in bullying (victims and witnesses), three were mothers of students, and 12 were professionals involved in social intervention (i.e. psychologists, teachers, social educators, and social workers). Initially, we planned to interview at least 20 more people, but we stopped collecting data when the same comments began to be reported. Therefore, it was considered that theoretical saturation had been reached (Arias and Giraldo,2011). 
Table 1. Description of participants.

\begin{tabular}{|c|c|c|c|}
\hline Sex & Age (years) & Profile & Role \\
\hline Man & 26 & Student & Victim \\
\hline Woman & 23 & Student & Victim \\
\hline Woman & 28 & Student & Victim \\
\hline Man & 27 & Student & Victim \\
\hline Man & 27 & Student & Victim \\
\hline Woman & 26 & Student & Victim \\
\hline Woman & 28 & Student & Witness \\
\hline Man & 25 & Student & Witness \\
\hline Woman & 29 & Student & Witness \\
\hline Man & 27 & Student & Witness \\
\hline Woman & 51 & Family & Mother \\
\hline Woman & 54 & Family & Mother \\
\hline Woman & 56 & Family & Mother \\
\hline Woman & 42 & Professional & Social Educator \\
\hline Woman & 43 & Professional & Social Educator \\
\hline Man & 49 & Professional & Teacher \\
\hline Woman & 48 & Professional & Teacher \\
\hline Woman & 38 & Professional & Psychologist \\
\hline Woman & 54 & Professional & Psychologist \\
\hline Man & 47 & Professional & Social Worker \\
\hline Woman & 35 & Professional & Social Worker \\
\hline Woman & 46 & Professional & Social Worker \\
\hline Man & 34 & Professional & Social Worker \\
\hline Woman & 38 & Professional & Social Worker \\
\hline Man & 36 & Professional & Social Worker \\
\hline
\end{tabular}

Source: Authors' own elaboration. 2020.

The selection criteria for the sample were the homogeneity of the overall topic and the heterogeneity of the content. Regarding homogeneity, we took into account the professionalism of the participants and their familiarity with the social setting. The heterogeneity criterion provided a diversity of participants, thereby allowing us to consider a range of ways perceiving and addressing bullying. Heterogeneity was reflected in variety of sociodemographic characteristics (e.g. sex, age, and place of residence). No restrictions were placed on the age of the participants. Ten participants were men and 15 were women; they were aged from 23 years to 56 years. No restrictions were placed on participation on the basis of place of residence, nationality, education, or employment status.

Inclusion criteria: having active professional involvement in the issue bullying, having experienced bullying directly or indirectly, and agreeing to participate in this study. Exclusion criteria: nonfulfillment of any of the inclusion criteria.
Data analysis: Procedure

We conducted an inductive thematic analysis to identify common patterns in the interviews. The analysis focused on describing and revealing the meanings of the data obtained in the interviews. A meticulous reading of the information collected and transcribed allowed us to identify, organize, analyze, and specify different themes. The construction of the emerging categories led to a better understanding of the phenomenon and allowed us to identify the themes related to school bullying (Arbeláez and Onrubia,2014).

The analysis consisted of six stages:

1. Data collection and preparation of the material for analysis.

We designed individual in-depth interviews for each participant. The objective was to obtain from each interviewee extensive sequences of text related to the previously established themes. In our case, the script focused on exploring their experience of bullying. The interview topics addressed personal views on bullying, the factors the participants considered key to the phenomenon, their opinion on the development and consequences of bullying, and their opinion on preventive measures. The interviews were conducted during February, March and April 2019. Each interview lasted from 67 to 74 minutes.

The objective and the procedure to be followed were explained to all the participants who agreed to collaborate in the investigation. Participants signed an informed consent form, which states their desire to voluntarily participate in the research without receiving any compensation. Similarly, they were informed about their right to refuse to participate or withdraw at any time from the process. It was also clarified that the information obtained through the interviews would be treated as confidential and anonymous, respecting the precepts of ethics and professional conduct of the Social Work discipline (Giménez,2014). The interviews were recorded with the consent of the participants to facilitate transcription.

\section{Literal transcription of the interviews.}

A comprehensive reading of the transcripts was conducted to ensure that they included all the information obtained during the interviews. 
3. Familiarization with the material through repeated readings, confrontation of messages, and follow-up of the main lines of argument (citations).

This process was independently conducted by each researcher. At this stage, a careful reading of the interviews by two researchers with experience in qualitative analysis served to identify the lines of argument that were part of the general themes.

4. Organization of the information into samemeaning categories in order to code the data.

This was accomplished by establishing relationships between the lines of argument and the same-meaning categories most frequently used by the participants to represent their reality about bullying. We ensured that the categories had been coded by the two researchers.

5. Searching for themes by detecting patterns in the coded categories.

The coded categories were examined to identify common patterns that could serve to build the themes. To guarantee the rigor and validity of this study, two measures have been used. First, intradata triangulation was used (Strauss and Corbin,1998). In this way, the categories derived from the analysis of the data in different fragments of the interviews and among the different participants were systematically compared. On the one hand, we study the experiences of the people who have been assaulted, their families and the observers of harassment situations and, on the other hand, the perceptions of different professionals who were involved in this type of abuse. Thus, the regularities and patterns were determined, which led to the definition of the categories that gave rise to the thematic blocks. Secondly, researcher triangulation was used (Denzin and Lincoln,1998), which consisted of contrasting the results of the coding of each researcher involved. Furthermore, a review of the subjects obtained after the codification was carried out by external researchers, who are experts in the subject and in this type of analysis (two national and one international expert). We used the following techniques: thematic identification and classification, contextual word searching, and coherence (Braun and Clarke,2006). The recording of the interviews is a fundamental element as a proof of validity and reliability of the data obtained for this research. This enables to overcome the possible bias of the researcher regarding the interpretation of their own results.

At this stage we used the software package Atlas. ti version 7.0. The process was divided into two distinct non-sequential phases: the textual level and the conceptual level. In the first phase (textual level), the software was used to facilitate the identification of lines of argument (citations) during code construction. In the second phase (conceptual analysis), the software was used to establish relationships between codes to identify themes. Therefore, we used the software to check and confirm the relationships previously proposed by the researchers.

\section{Consensual report.}

A consensual report was written by the researchers that included the themes obtained that would assist in describing and explaining the phenomenon of bullying.

\section{RESULTS}

Four themes were identified in the interviews: Theme 1:"Descriptive elements of bullying"; Theme 2:"Bullying is a social issue"; Theme 3:"Normalizing bullying hidden behind other types of violence"; and Theme 4:"An integrated struggle against bullying". The interrelated discursive strategies detected in the themes helped us to know and better understand the phenomenon. The different discursive strategies or categories that comprise each of the themes are legitimized through certain fragments obtained in the interviews.

The following section describes the participant's opinions on the issues that guided the interviews. During the interviews, some topics and examples emerged from the participants' experiences that were explored in more depth. Their discourse is illustrated by using textual quotations from the participants. The selection of fragments was based on the consideration that they explicitly describe the analysis being carried out. Thus, it is understood that they are verbatim quotes that illustrate and give sense to the interpretation and understanding of bullying.

Figure 1 exemplifies the themes and the discursive strategies that explain them through a conceptual map that helps to understand the report presented. 


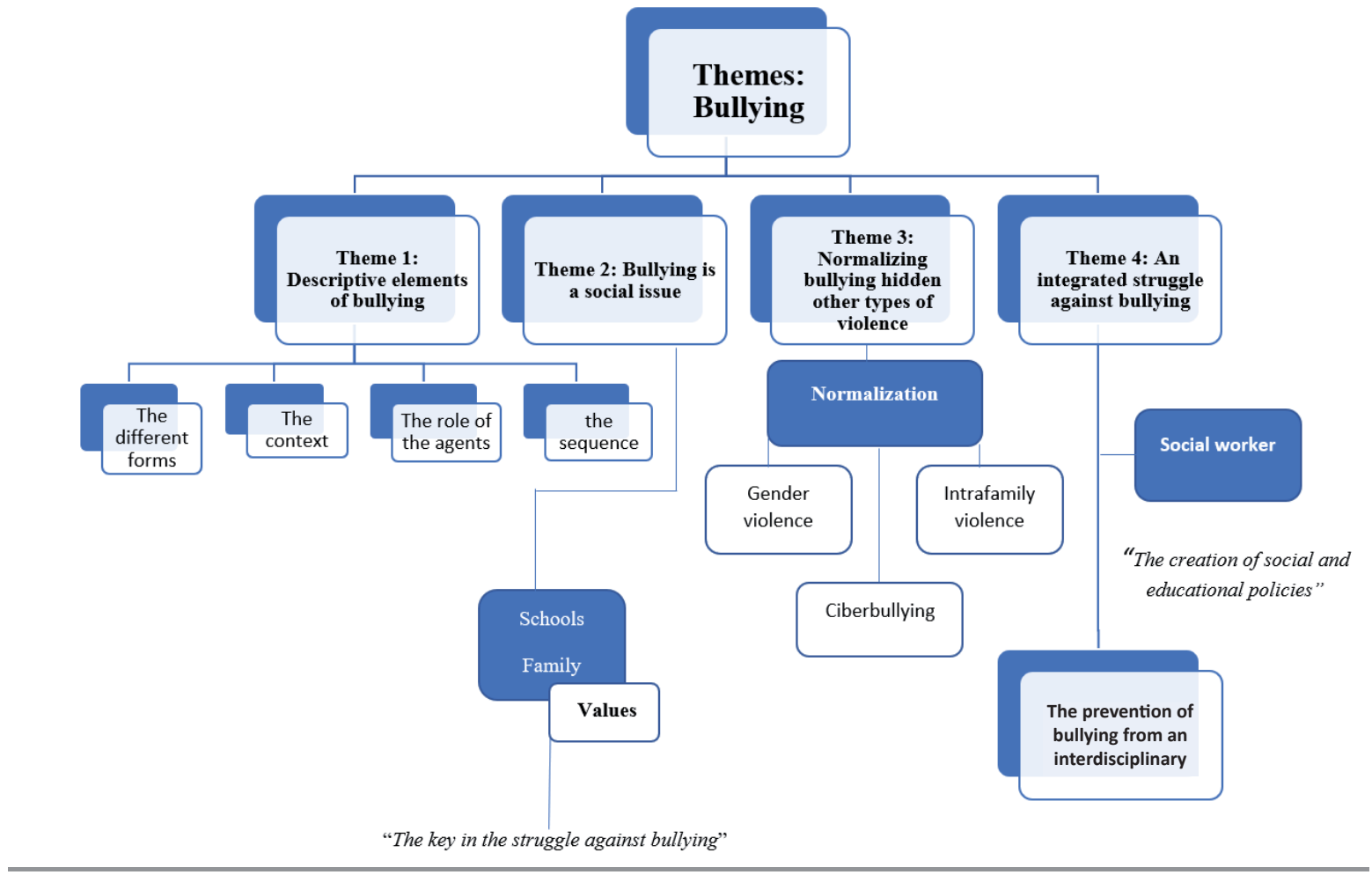

Source: Authors' own elaboration. 2020.

Figure 1.Themes and discursive strategies.

Theme 1: Descriptive elements of bullying

This theme illustrates the different lines of argument the participants used to define and explain what they understood by bullying. Thus, we were able to clarify the main elements used to characterize bullying. We obtained explicit descriptions of different forms of peer abuse, the sequence involved in the process of bullying, the context, and the role of the agents involved in victim-bully dynamics.

Del Moral, Suárez, Moreno, and Musitu (2014) suggested that bullying is a complex construct, rather than a single and clearly defined concept. Although there are considerable variations in the definition of bullying, the participants typically described it as repeated behavior on the part of one or several people over time. They also specified that this behavior seeks to harass, scare, or make fun of a peer with the intention of hurting them.

It's abuse, that is, it's a behavior... and it can be hitting, insulting, hurting, scaring, or teasing a classmate. It's abuse toward another person, repeated over time, it has to happen several times and normally one child does it to another, but other children join in later. Also, there's a clear intention to cause harm (man, 26 years, victim).

In addition to being recurrent and intentional peerto-peer abuse, there is a power imbalance between the victim and aggressor. Consequently, this situation creates a sense of helplessness in the victims and their family.

Bullying occurs when a student or a group of students hassle or try to make life impossible for another one who is normally at a disadvantage. Of course, this means that we are always helpless (...) (woman, 51 years, family member).

The reasons behind bullying are confusing and diverse. The participants repeatedly identified several issues that lead to bullying. The more common reasons offered were physical appearance, being different, or simply being "disliked".

The way I experienced it, bullying is, youths, boys, and girls from the same class as you, who for one reason or another, it can be the dumbest thing, 
they start hating you, they've got it in for you, right? Basically, they've got it in for you and the gang who dislike you gets bigger and they start picking on you as soon as you stand out in some way. I think that being different in some way makes them jealous... (woman, 23 years, victim).

Another perceived reason for bullying is the attempt to blame the person being bullied for the aggression: "You were looking for it, you deserve it for looking too much ..." (man, 25 years, witness).

The mother of the girl who hit my daughter didn't want to do anything about it and she said that my daughter made it up. So, between that and my daughter being in such bad shape she had to have therapy, we were also in a very bad shape ...., and so the situation was one of helplessness (woman, 54 years, family member).

The narratives showed that bullying occurs as a gradual process. Some participants used the image of a ladder to describe the process. This is how it was described by a participant:

Bullying is like a ladder... maybe, on the first step, it's just a look, like we said, you're new at school and they start looking at you, they see you as the weakest one, and the jokes start. The next step is giving you nickname or name-calling, next comes an insult; depending on how things develop, the hassle gets worse or better (woman, 28 years, victim).

Family members, bullied people, friends, and professionals agree that bullying should be classified according to the ways bullying is perpetrated. According to the participants, the most common kinds of bullying are physical and verbal violence, and direct or indirect violence: "Ugh... like ... there's non-stop insults, swearing, laughing at you about the stupidest things... and, well, physically, there's pushing, hitting, knocking you down, you know..." (woman, 26 years, victim).

The participants referred to direct abuse when they were the target of open attacks: "...someone arrives, and gives you a shove and hits you ...", "... and well, about physical hassle, I've seen people who've done that" (woman, 28 years, witness). They also referred to indirect abuse when they were excluded from their peer group: “... they laughed at me without the teachers noticing it because I was chubby, they wouldn't let me play because I was fat". They excluded me from everything, especially the "know- it-all girl..." (woman, 23 years, victim). In this sense, physical violence is closely related to direct violence and verbal violence is a type of indirect violence.

According to the participants' discourse, the school is usually the main setting in which bullying takes place, but it is not the only one. In fact, the following quote shows that bullying is transferred to meeting places in the neighborhood (i.e. parks, squares, extracurricular activity premises) and to social media via internet.

"...But the aggression happened here, I mean, the physical aggression was here inside the residential area, in summer, in the pool, they threw her into the pool and they wouldn't let her out, she and another girl. It was then when I really saw that something was going on, that this wasn't just kids' stuff... But, I also know other types of aggression all related to new technologies, cyberbullying..." (woman, 56 years, family member).

Although bullying occurs in other contexts, the interviewees agreed that in other settings it is a consequence of the relationships created at school.

It happens at school and I'm sure that it happens for the first time at school. But we have to remember that parents, teachers, the headteacher, everybody... we are all responsible for the violence that happens at school, but that it transfers to parks, to the streets, and now to social media (woman, 42 years, social educator).

However, in some cases, it was pointed out that the school is not the cause or the only place where bullying arises, and that schools could be part of the solution. The next theme shows that school and family settings, as well as the education and values acquired in these settings, are key in the struggle against bullying.

Theme 2:Bullying is a social issue

In line with the definition offered by Tello (2005), and by the participants' discourses, bullying is the mirror of a troubled society that has an economic structure unable to meet the needs of the population. That is, a society in which current sociopolitical restructuring is leading to the break-up of social cohesion.

Our society is like a pool of sharks... the big fish eat the little fish, but it's everywhere... in politics, the economy, everywhere... What's clear is that, if the big fish try to eat the little fish, but a load of medium-size ones come to the rescue, the big fish won't be able to eat them (man,49 years, teacher). 
During discourse analysis we found that viewing bullying as a social problem seemed to cause debate among the interviewees. Although most of the participants agreed that the family and the school are the carriers of the seeds of violence, they also stated that the family and schools are the settings in which children should taught and guided towards other behavior.

These are basic educational and ethical issues, and they must be addressed in childhood, and we need to raise awareness among students, families, schools, and society as a whole of the current relevance of this problem (woman, 38 years, psychologist).

Values should be taught at school, if the school is religious, religious values, and if the school is agnostic or atheist, values such as ethics, philosophy, morality, but most of these things have been lost at school. Not to mention the new family values (man, 47, social worker).

Violence is generated in the family and at school. We explore this assertion in Theme 3; however, it implies that some types of abuse, such as bullying, have become socially accepted and normalized. Participants expressed the view that violence in the home and school has led to "a lack of prevention and the early detection of bullying" (woman, 35 years, social worker).

Some participants believed that "society is the mold that shapes violent behavior ..." (woman, 46 years, social worker). In this sense, some participants said that "what happens at school is a reflection of what happens in society" (woman, 38 years, psychologist). Several interviewees asserted that bullying has an effect on society because both aggressors and victims will live in a society and carry with them the "mark or footprint" of this violence.

Cerezo and Rubio (2017) suggested that the family and school are the most typical channels through which violent behavior is transmitted and that such behavior forms part of the historical and cultural legacy of a society. Society itself contributes to the continuity and permanence of bullying because social problems are factors that trigger violent behavior in the family and at school. In fact, there is an emerging normalized discourse within society regarding violent behavior that refers to everyday abuse among peers: "...like the case of Jokin, Tania, etc... it's seen as a something normal, just children fighting..." (man, 49 years, teacher).
This process is reciprocal and bidirectional. Participants reported that bullying has severe repercussions not only on individuals, but also on society as a whole:

There are physical consequences, but also school absenteeism. Boys and girls stop going to school and in some cases they commit suicide. This has severe social repercussions such as school failure, social isolation, problems in social relationships ... (man, 34, social worker).

Participants also expressed the need for schools and family to work together in an attempt to eradicate bullying, because these are the main environments in which people learn interpersonal relationships. Therefore, families and schools should have access to suitable tools to prevent violence. According to Hamodi and Jiménez (2018), the lack of efficient instruments in these settings facilitates the build-up of behavior issues such as aggression, low self-esteem, depression, feelings of inferiority, and insecurity.

Obviously, bullying is a problem that concerns society as a whole, and therefore, social and community workers and educators cannot ignore it. Thus, as pointed out by the professionals interviewed, "...we always need to receive ongoing information, guidance, and training on the different problems of today's society" (woman, 35 years, social worker). "We cannot ignore problems having such a big impact on our society and, above all, we have to teach the institutions involved how to prevent it" (woman, 38 years, psychologist).

In general, there is a consensus that value-based education is the key to prevent bullying. Along these lines, some participants mentioned that in recent years there has been a social process of ". Changes in traditional values, such as being a friendly, peaceful, good, or empathetic person ...", and “...now power, strength, individualism, consumerism dominate as the fundamental values..." (woman, 43 years, social educator).

So, healthy family and schools environments have to be encouraged to ensure a better integration in society. The participating professionals, families, and victims agreed that it is important to teach children values, social skills development, diversity, and empathic behavior both at school and in the family setting.

This should come from home, that's where you get start getting educated; you get education and values at 
home... if you get them at home... the school must continue to support these values... (woman, 48 years, teacher).

So, if they don't teach you values at home ... of course, you know your kid very well at home... I think we should be more strict at home and in the centers (woman, 54, psychologist).

That said, the professionals also confirmed the need to know more about children's interpersonal relationships in their social, family, and cultural settings to better understand peer abuse.

We have to dig into the root of the problem, it's for sure that family variables such as domestic violence and other psychosocial variables are having an effect... (woman, 46, social worker).

Theme 3: Normalizing bullying hidden behind other types of violence

This theme shows that bullying is not a behavior that occurs in isolation from other types of violence. The participants considered that bullying is interrelated with gender violence and intrafamily violence, and that it has a close connection with cyberbullying.

Well, I can tell you that except for two or three people, everyone who bullied me had parents with problems; one [of the dads] had been in jail for beating up his wife and, currently, some [of the bullies] are dealing drugs, and stuck in these kinds of problems..., all this makes the bully vent their anger on any victim that crosses their path (man, 27 years, victim).

Currently, as a result of new technologies, the concept of bullying has been extended to a more extended and dangerous dimension known as "cyberbullying". The way bullying happens today is related to this kind of violence and it has expanded ... (woman, 38 years, psychologist).

Sociocultural, family, and digital violence are considered triggers that permit, tolerate, produce, and replicate violent behaviors such as bullying. People learn to live with violence and thus the existence of violence is strengthened and normalized in settings such as the school "...of course, I think that if they see it at home, they'll see it as normal ..." (woman, 45 years, social worker). The participants pointed out that these types of violence "... are true risk factors and encourage harassment ..." (man, 34 years, social worker). What happens in other settings has a direct or indirect effect on the educational setting. The professionals interviewed emphasized that if bullying is dealt with without taking into account other settings "... you would only be looking at the tip of the iceberg of a much larger problem, where different types of violence feedback on each other"(woman, 54 years, psychologist).

In general, the interviews suggested that there was a tendency for bullying to become normalized. In fact, most interviewees said that the main reason these situations are not addressed appropriately is because they are seen as "kids' stuff" (woman, 29 years, witness). Hence, there is a tendency to assume that bullying is a normalized unavoidable phenomenon.

It's normalized violence and it can't be avoided, because it's normal for children to insult each other, to call each other names, to yell at each other; that's seen as normal, as "kids' stuff"... (woman, 51 years, family member).

In many cases, this normalization is particularly promoted by adults, who state that bullying has always existed because "fights between children are kids" stuff and they have solved them themselves" (woman, 51 years, family member). Aggressors view this as implicit consent, which motivates them to continue bullying their peers. Normalization reinforces the inability of the victims to cope with bullying, whereas it encourages the passivity or indifference of observers toward this behavior (Cano and Vargas, 2018).

In this line, the participants pointed out that "the code of silence dominates bullying in schools..."; "So it [normalization] shuts them and us up and the situation becomes worse" (man, 27 years, witness). This makes the reality of bullying complex and difficult to identify, which therefore hinders its prevention and interventions. Some interviewees called it "silenced violence", which has a high social cost. However, it is not usually reported for the following reason: "I was afraid to report it because I would have suffered even more rejection..." (woman, 54 years, family member).

"Everyday" harassment remains invisible, and we lack systematic institutional responses for prevention and early detection. For this reason, bullying must be included in a wider strategy aimed at an integrated struggle against violence, as addressed in the following theme. 
Forsberg and Thornberg (2016) warned some time ago that we were facing a social problem that required integrated approaches, similar to the ones used for other types of violence (Gámez, 2012). Thus, it is relevant to encourage cooperation between parents, teachers, intervention specialists, and society as a whole.

Theme 4: An integrated struggle against bullying

This final theme addresses a range of discursive strategies that include approaches to intervention in bullying, discrepancies between teachers' and students' perceptions of violent classroom behavior, the prevention of bullying from an interdisciplinary perspective, and intervention protocols in bullying.

As already noted in previous themes, the participants claimed that peer violence and intervention not only depend on teachers and students, but also on the way in which families and society perceive and interpret this reality. In fact, student victims, teachers, and witnesses had different perceptions of violent classroom behavior. For example, students said "...my teachers did nothing to solve it" (woman, 28 years, witness), whereas teachers said that "... sometimes we don't feel obliged to intervene because we don't see it as abuse and we need to know more about what is going on..." (man, 49 years, teacher).

Gotzens, Castelló, Genovard, and Badía (2003) suggested that not everyone views disruptive classroom behavior in the same way. Some interviewees, especially teachers, stated that such behavior is triggered by personal, family, or social issues and therefore is not exclusively within their scope of responsibility. In their defense they stated that "...although everything is stipulated, written, and regulated, it isn't implemented [because of] lack of money, or lack of interest, or because, after all, this isn't my job, because if parents or others don't get involved..." (woman, 43 years, social educator).

Therefore, this issue is a great challenge for victims and their families. Essentially, they do not know how to handle this problem and or where to go for help, apart from the school and teachers. Despite expecting a response or a solution from these sources, it is common experience that none are provided.

Schools have tried to apply programs and protocols to prevent bullying becoming normalized. As described by the participants, although new initiatives and regulations have also been implemented "... they are far from ideal because they haven't filtered into the school culture or students' relationships" (woman, 42 years, social educator).

We are talking about the public administration. The legislation for bullying. There are ... some topdown protocols from the Administration and ... they aren't complied with. There is a legislated bullying observatory, but it doesn't exist; I mean, it exists on paper, but it isn't working, and it doesn't do the job it's supposed to do (woman, 43, social educator).

However, most of the participating social workers, psychologists, and social educators agreed on the need for all community sectors to be involved in the creation of "rules for being together" that can be accepted and respected by everyone.

There seems to be interest in improving approaches to this issue, but there is a lack of adequate material and an effective method to implement such measures. I believe that if we work towards building on the foundation we already have, and we all get involved in creating new educational projects, we could massively improve the situation (woman, 46 years, social worker).

When these participants spoke of collaboration between several social agents, they were mainly referring to being able to sustain coordination and support between the different professionals involved, the family, and the school.

We don't want to be told "here's 50 euros to print brochures and distribute them at the school door". What we are really looking for is political commitment, that political needs are established to eliminate this problem, and they need to understand that multidisciplinary teams need to be created to educate teachers, students, and parents. Working on the street with them, not only for them (man, 36 years, social worker).

They also express the need to include new professionals, such as social workers, in the education system. The participating social workers offered explanations such as the following:

With bullies it's difficult to work on a personal level, and with "spectators" as well, because parents rarely come here and tell you "help me to end this"; so it's essential to work with them from within their comfort zone. Above all, we would need our own space in schools, in classrooms, making them understand that this isn't the way to behave (woman, 38, social worker). 
During university education, social workers demand more and better training about this type of violence. At times, it is difficult for them to verify that what the child is going through is bullying rather than another type of violence. This need is shared by other professionals involved, including teachers.

You need to get a degree in school bullying. It isn't enough to finish your degree and say here I am. Training in this area is very limited. You shouldn't believe that you'll be able to leap into this world without first learning on your own and becoming an expert. Because working with children is like working with modeling clay; their shape will depend on the hands that work with them (man, 36 years, social worker).

Thus, it is argued that, to prevent bullying, further training is needed by teachers and any other professionals who have to identify the problem and conduct interventions. "Relationships between teachers and families have to be encouraged and local administrations have to get more involved in schools" (woman, 35 years, social worker).

The role of teachers should be to encourage new ways of relating and interacting in order to mitigate bullying. Social workers should also play a key role in the creation of social and educational policies aimed at improving daily interactions between victims, the family members, and schools. They should also monitor adherence with the measures implemented.

Thanks to their training, social workers should be the cornerstone of interdisciplinary teams against bullying. They should actively participate in the development of public policies, and in the supervision and follow-up of policies in actual schools (man, 34 years, social worker).

Some of the professionals also wanted to raise awareness regarding the relevance of social workers in encouraging and facilitating self-actualization and empowering people to eliminate bullying. This line of argument is exemplified in the following quote:

During bullying, victims find themselves in a state of total helplessness and insecurity. In this sense, the social worker is ideally qualified to position herself as a reference in the process of empowerment, increasing resilience and improving the victim's self-esteem (woman, 38 years, social worker).
This suggests the need to enhance inter- and transdisciplinary relationships. Social-ecological intervention models that address bullying as well as integral prevention protocols could be created by recognizing the specificities and potentials of each discipline involved.

\section{CONCLUSIONS}

This study addressed the reality of school bullying by exploring the discourse of professionals, victims, friends, and family. We used thematic inductive analysis of the transcriptions obtained from interviews with the participants. Four main themes were identified and used to understand general and specific aspects of bullying: Theme 1 "Descriptive elements of bullying", Theme 2 "Bullying is a social issue", Theme 3 "Normalizing bullying hidden behind other types of violence", and Theme 4 "An integrated struggle against bullying". We now present the conclusions drawn from each theme.

Theme 1: Descriptive elements of bullying

Bullying has been defined and conceptualized from different perspectives (Ronald, 2010). Few studies have examined the phenomenon of bullying using the voices of those involved. This study research did not attempt to analyze bullying using the definitions provided in most of the academic literature. In line with the work of Liefooghe (2003) and Pulido, Montalbán, Palomo, and Luque (2008), our objective was to deepen our understanding of the way the social agents involved (i.e., relatives, victims, and professionals) use the term, rather than attempting to discover the true nature of bullying. Thus, we avoided using the term "bullying" as a synonym of other types of school violence.

We confirmed that some elements are always present in bullying situations. According to Hymel and Swearer (2015), the key aspects that have to be present to identify bullying are a desire to harm, a power imbalance between peers, and repeated aggression. The discourse of our participants confirmed the presence of these characteristics in bullying situations. The distinctive features of bullying must be present and taken into account to develop proposals for prevention and intervention. In this sense, the first step in addressing the issue of bullying is to listen to the voice of the agents involved such that the phenomenon can be 
defined and differentiated from other types of violence. Based on this premise, we suggest the following: the concepts of social power and abuse of power should be taken into account when creating prevention programs; situations that encourage aggressive behaviors should be prevented from arising; and interventions must be adapted and specific to bullying.

Theme 2: Bullying is a social issue

Recent research has addressed the prevalence of bullying in schools, but there has been less research on the phenomenon in other settings. Thus, we have data on the age of people involved in bullying and the behaviors that trigger it (Carrillo, 2018; Prieto, Jiménez and Carillo, 2010). To understand bullying, the participants in this study highlighted the importance of improved knowledge concerning interpersonal relationships in the social, family, and cultural settings of the people involved. In fact, in line with the results of Cerezo and Rubio (2017), our study shows that social and cultural problems appear to be the triggers of school bullying. In this sense, several qualitative studies have explained bullying from the social and educational factors of victims and aggressors (Gallego and Rodríguez,2019; Pulido and Tarancón,2018; Smit,2018). Furthermore, this phenomenon is approached from the conceptions and perspectives of witnesses, family members and professionals, with special attention to Social Work professionals. We also found that some of the discourse made reference to bullying as normalized social interaction. This result is in line with other research (Cuadrado-Gordillo, 2012; Ryan and Morgan, 2011).

Based on the foregoing, we suggest that bullying is a social phenomenon that changes according to the characteristics of the social and cultural setting. Bullying needs to be investigated in more depth from a critical and reflexive perspective that takes into account the context that gives rise to bullying and the sociodemographic characteristics of the agents involved in the phenomenon.

Theme 3: Normalizing bullying hidden behind other types of violence

As Yubero, Larrañaga, and Martínez (2013) suggested, several types of violence seem to have a close relationship with bullying. The participants saw a link between domestic violence, gender abuse, and bullying. Therefore, violent interactions that are labeled as bullying should be differentiated from each other
(Ortega,2010). Castillo (2011) proposed that this type of differentiation could facilitate the provision of better recommendations to improve interpersonal relationships at school and in other settings. In order to understand bullying, the social and family context of people involved should be known. It should also be determined whether other types of violence coexist with bullying or whether they are at the root of bullying behavior.

The participants stated that bullying is a reflection of what happens in other settings (Ayala-Carrillo,2015; Pulido and Tarancón,2018). Therefore, bullying should be addressed from a multidisciplinary perspective that includes all the professionals who interact with families and schools. In this way, cooperation between professionals and institutions should lead to the emergence of healthier social environments in which values-based education is the key to interventions (Jara, Casas and Ortega,2017).

Theme 4: An integrated struggle against bullying

In line with the results obtained by Díaz-Aguado (2005), the results of this study also highlight the need to create interdisciplinary teams that cooperate with families, schools, and other social agents. Thus, interdisciplinary collaboration should become the keystone by which to eradicate bullying.

According to Samaniego and Bermúdez (2015), social workers should play a key role in these interdisciplinary teams by identifying new resources and programs to more effectively address the problem. In addition, social workers have the skills needed to conduct interventions with all the agents involved. In their role as expert witnesses, social workers can also report on the social factors that may have influenced specific bullying behavior. It is understood that Social Services are a key element to detect and modify those situations of social vulnerability. Therefore, these services are essential for the prevention and multidisciplinary intervention of this type of violence. This study advocates for strengthening the coordination of these services with educational centers. In addition, it is argued that the figure of the social worker in the educational field is necessary and fundamental because they will contribute to the improvement of interpersonal relationships between students, family members, school staff and other professionals. 
The key principles of social work promote change, social development, inclusion, and social cohesion (Barahona, 2016). In this sense, the main lines of action of social workers are to strengthen and empower people in difficulty with the aim of improving their wellbeing. Social work itself is governed by the principles of social justice, human rights, collective responsibility, and respect for diversity. According to the results of our study, social workers should be incorporated in the education system because their multidisciplinary training would act as a key resource in the struggle against bullying. Social workers could prevent bullying through running preventive campaigns, awareness campaigns, conducting interventions via interdisciplinary workshops, and acting as mediators between the agents involved.

Psychosocial intervention professionals, and specifically social workers, need access to knowledge and suitable tools to deal with bullying in different settings. The ecological approach of this study has shed light on the phenomenon of school bullying by showing that it is a social problem associated with other types of violence. The results of the study may also be useful in the design of more effective strategies and new prevention and social intervention programs.

One of the main limitations of this study is that it lacked the participation of any aggressors. According to the results obtained in Theme 1 , this limitation is closely related to the fact that school bullying has become normalized by its being perceived as "kids just teasing each other". Ortega and Mora-Merchán (2008) suggested that it is difficult to gain access to samples of aggressors because they do not usually acknowledge the seriousness of their behavior. Given that we used purposive sampling, caution should be employed when applying the results to other social contexts. Nevertheless, the knowledge derived from this study could be used as a good starting point for other studies.

In conclusion, this study contributes to the study of bullying by making visible the experiences of the all agents involved, and by urging increased commitment and responsibility on the part of the administration charged with prevention and intervention. This study represents an invitation to further reflection on this phenomenon and its implications for social and community intervention.
Studies on peer-to-peer abuse generally employ quantitative methods. The use of qualitative methods, or a combination of both approaches, will help us to gain a more comprehensive understanding of the phenomenon. To avoid reaching premature conclusions on an issue as complex as bullying, a more rigorous approach is needed in order to reveal its particularities, specificities, and dynamics in different settings. Such an approach would increase our knowledge and expand our options regarding interventions. It would also lead to more effective and efficient prevention and intervention plans and strategies developed in cooperation by public administrations, social bodies, professionals, and citizens.

\section{REFERENCES}

Alvites, C.G. (2019). Adolescencia, ciberbullying y depresión, riesgos en un mundo globalizado. Revista Científica Electrónica de Educación y Comunicación en la Sociedad del Conocimiento, 19(1), 210-234. https://doi.org/10.30827/ eticanet.v19il.11867

Arbeláez, M.C. \& Onrubia, J. (2014). Análisis bibliométrico y de contenido. Revista de investigaciones UCM,23,14-21.

Arias, M.M. \& Giraldo, C.V. (2011). El rigor científico en la investigación cualitativa. Revista Temática, 29(3),501-514.

Arias, W.L. (2015). Conducta prosocial y psicología positiva. Avances en Psicología, 23(1),37-47.

Ayala-Carillo, M.R. (2015). Violencia escolar: un problema complejo. Revista Ra- Ximhai 11(4), 493-509. https://doi. org/10.35197/rx.11.01.e2.2015.36.ma

Barahona, M.J. (2016). El Trabajo Social: Una Disciplina y Profesión a la Luz de la Historia. Madrid: Departamento de Estudios e Imagen corporativa.

Braun, V. \& Clarke, V. (2006). Using thematic analysis in psychology. Qualitative Research in Psychology, 3(2),77101. https://doi.org/10.1191/1478088706qp063oa

Cabruja, T., Íñiguez, L. \& Vázquez, F. (2000). Cómo construimos el mundo: relativismo, espacios de relación y narratividad. Anàlisi: Quaderns de comunicació i cultura,25,61-94.

Cano, M. M. \& Vargas, J.E. (2018). Actores del acoso escolar. Revista Médica de Risaralda, 24(1),60-65. https://doi. org/10.22517/25395203.14221

Carrillo, A. (2018). El acoso escolar como forma de violencia en la enseñanza secundaria, una visión legal del problema. Revista sobre la infancia y la adolescencia, 14,1-22. https://doi.org/10.4995/reinad.2018.6780

Castillo, L.E. (2011). El acoso escolar. De las causas, origen y manifestaciones a la pregunta por el sentido que le otorgan los actores. Revista Internacional de Investigación en Educación,4(8),415-428.

Cerezo,F.\&Rubio,FJ. (2017). Medidasrelativasalacosoescolar y ciberacoso en la normativa autonómica española. Un estudio comparativo. Revista electrónica interuniversitaria 
de formación del profesorado,20(1),113-126. https://doi. org/10.6018/reifop/20.1.253391

Cuadrado-Gordillo, I. (2012). Repetition, power imbalance, and intentionality: Do these criteria conform to teenagers' perception of bullying? A role-based analysis. Journal of Interpersonal Violence,27,1889-1910. https://doi. org/10.1177/0886260511431436

Del Moral, G., Suárez, C., Moreno, D., \& Musitu, G. (2014). The Hip-Hop Music as a Preventive Resource for Bullying: Analysis of 10 Spanish Hip-Hop Songs about Bullying. Qualitative Research in Education,3(1),1-29. https://doi.org/10.4471/qre.2014.34

Denzin, N.K. \& Lincoln, Y.S. (1998). Collecting and interpreting qualitative materials. London: Sage Publications.

Díaz-Aguado, M.J. (2005). Por qué se produce la violencia escolar y cómo prevenirla. Revista Iberoamericana de Educación,37,17-47. https://doi.org/10.35362/rie370838

Domínguez, L. \& Montalbán, F.M. (2017). Alternativas en el debate sobre el matrimonio igualitario en Europa y América Latina. Andamios,14(35),335-357. https://doi. org/10.29092/uacm.v14i35.582

Espelage, D.L. \& Swearer, S.M. (2004). Bullying in American schools: A social-ecological perspective on prevention and intervention. Mahwah, N.J.: Erlbaum. https://doi. org/10.4324/9781410609700

Finkelhor, D., Turner, H., \& Hamby, S.L. (2012). Let's prevent peer victimization, not just bullying. Child Abuse \& Neglect,36,271-274. https://doi.org/10.1016/j. chiabu.2011.12.001

Forsberg, C. \& Thornberg, R. (2016). The social ordering of belonging: Children's perspectives on bullying. International Journal of Educational Research,78,13-23. https://doi.org/10.1016/j.ijer.2016.05.008

Gallego, A.M., Agudelo, J. F., Vásquez, O.C., Restrepo, M.C., \& Gálvez, A. (2019). El cultivo de la convivencia: una oportunidad para prevenir situaciones de acoso escolar. Revista Infancia Imágenes,18(2),159-170. https://doi. org/10.14483/16579089.14025

Gallego, M.G. \& Rodríguez, L.M. (2019). Imaginario sobre la intervención ante el bullying bifóbico en trabajadores/ as sociales gallegos. Alternativas,26,35-58. https://doi. org/10.14198/ALTERN2019.26.02

Gámez, M.J., (2012). Sobre los modos de visibilización mediático-política de la violencia de género en España: Consideraciones críticas para su reformulación. OBETS. Revista de Ciencias Sociales, 2,185-213. https://doi. org/10.14198/OBETS2012.7.2.02

Giménez, V.M. (2014). Cuestiones éticas en la investigación en Trabajo Social y estrategias para una investigación éticamente responsable. AZARBE,3,187-195.

Glaser, B. \& Strauss, A. (1967). The Discovery of Grounded Theory: Strategies for Qualitative Research. New York: Aldine Publishing Company. https://doi.org/10.1097/00006199196807000-00014

Gómez, A. (2013). Bullying: El poder de la violencia. RMIE, 18(58),839-870.

Gotzens, C., Castelló, A., Genovard, C., \& Badia, M. (2003). Percepciones de profesores y alumnos de E.S.O. sobre la disciplina en el aula. Psicothema,15(3), 362-368.
Hamodi, C. \& Jiménez, L. (2018). Modelos de prevención del bullying: ¿qué se puede hacer en educación infantil? IE Revista de investigación educativa de la REDIECH,9(16), 2950. https://doi.org/10.33010/ie_rie_rediech.v9i16.106

Herrera, M., Romera, E.M., \& Ortega, R. (2018). Bullying y Cyberbullying en Latinoamérica. Un estudio bibliométrico. Revista mexicana de investigación educativa,23(76), 125-155.

Hymel, S. \& Swearer S.M. (2015). Four decades of Research on School Bullying. An Introduction. American Psychological Association,70(4),293-299. https://doi.org/10.1037/ a0038928

Jara, N., Casas, J.A. \& Ortega, R. (2017). Proactive and reactive aggressive behavior in bullying: The role of values. International Journal of Educational Psychology,6(1), 1-24. https://doi.org/10.17583/IJEP.2017.2515

Liefooghe, A. (2003). Employee accounts of bullying at work. International Journal of Management and Decision Making,4(1), 24-34.https://doi.org/10.1504/IJMDM.2003.002486

Machimbarrena, J.M., Calvete, E., Fernández, L., Álvarez, A., Álvarez, L. \& González, J. (2018). Internet Risks: An Overview of Victimization in Cyberbullying, Cyber Dating Abuse, Sexting, Online Grooming and Problematic Internet Use. Res. Public Health,15,1-15. https://doi. org/10.3390/ijerph15112471

Mateu-Martínez, O., Piqueras, J.A., Rivera-Riquelme, M., Espada, J.P. \& Orgilés, M. (2014). Aceptación /rechazo social infantil: relación con problemas emociones e inteligencia emocional. Avances en Psicología, 22(2), 205213.https://doi.org/10.33539/avpsicol.2014.v22n2.190

Méndez, I. \& Cerezo, F. (2018). La repetición escolar en educación secundaria y factores de riesgo asociados. Educación XXI,21(1), 41-61.https://doi.org/10.5944/ educxx1.20172

Moreno, C. B., Tabullo, A. \& Segatore, M.E. (2019). Empatía, conducta prosocial y bullying. Las acciones de los alumnos espectadores. Estudios sobre educación,37,113-134. https:// doi.org/10.15581/004.37.113-134

Nocito, G. (2017). Investigaciones sobre el acoso escolar en España: Implicaciones psicoeducativas. Revista española de orientación y psicopedagogía,28(1), 104-118. https://doi. org/10.5944/reop.vol.28.num.1.2017.19361

Olweus, D. (1998). Conductas de acoso y amenaza entre escolares. Madrid: Ediciones Morata.

Ortega, R. (2010). Agresividad injustificada, bullying y violencia escolar. Madrid: Alianza Editorial.

Ortega, R. \& Mora-Merchán, J.A. (2008). Las redes de iguales y el fenómeno del acoso escolar: explorando el esquema dominio-sumisión. Infancia y Aprendizaje,31,515-528. https://doi.org/10.1174/021037008786140922

Ovejero, A. (2013). El acoso escolar: cuatro décadas de investigación internacional. En A. Ovejero, P.J. Smith \& S. Yubero (Coords.), El acoso escolar y su prevención. Perspectivas internacionales (pp. 11-56). Madrid: Biblioteca Nueva.

Postigo, S., Schoeps, K., Ordoñez, A., \& Montoya-Castilla, I. (2019). ¿Qué dicen los adolescentes sobre el acoso escolar? Anales de Psicología,35(2),251-258. https://doi. org/10.6018/analesps.35.2.301201. 
Prieto, M.T., Jiménez, J. \& Carrillo, J.C. (2010). Bullying. Maltrato entre alumnos: El lado oscuro de la escuela. Estrategias de intervención con historietas. Buenos Aires/ Ciudad de México: Novedades Educativas.

Pulido, L. \& Tarancón, P. (2018). Opiniones y experiencias respecto al bullying: estudio cualitativo en un instituto de educación secundaria de la localidad de Albacete. Revista de la Facultad de Educación de Albacete,33(2),29-45.

Pulido, M., Montalbán, M., Palomo, A. \& Luque, P. (2008). Acoso psicológico, organización e identidad: análisis desde un foro virtual. Athenea digital,13, 133-152. https:// doi.org/10.5565/rev/athenead/v0n13.349

Ronald, E. (2010). Agresividad injustificada, bullying y violencia escolar. Madrid: Alianza Editorial.

Ryan, A. \& Morgan, M. (2011). Bullying in secondary schools: An analysis of discursive positioning. New Zealand Journal of Educational Studies, 46(1),23-34.

Samaniego, J.L. \& Bermúdez, D. (2015). Discriminación hacia jóvenes homosexuales en su entorno educativo (Tesis de Licenciatura). Cuenca, Ecuador: Universidad de Cuenca.

Sánchez, C. \& Cerezo, F. (2010). Variables personales y sociales relacionadas con la dinámica del bullying en escolares de Educación Primaria. Electronic Journal of Research in Educational Psychology,8(3),1696-2095.

Smit, B. (2018). Understanding bullying relationally. South African Journal of Education, 38, 1-8. https://doi. org/10.15700/saje.v38nsla1586

Strauss, A. \& Corbin, J. (1998). Basics of qualitative research: Techniques and procedures for developing grounded theory, 2nd Edition. Thousand Oaks, CA: SAGE Publications.

Tello, N. (2005). La socialización de la violencia en las escuelas secundarias proceso secuencial a la descomposición social. Revista Mexicana de Investigación Educativa, 10(27), 1165-1181.

Twemlow, S.W. \& Sacco, F.C. (2012). Preventing bullying and school violence. Washington, DC, London, England: American Psychiatric Publishing.

Vázquez, O. (2005). ElEspacio Europeo de Educación Superior y el Trabajo Social en España. Portularia,5(1),239-255.
Yubero, S., Larrañaga, E., \& Martínez, M. I. (2013). Familia, comunicación y conductas de acoso. En A. Ovejero, P. K. Smith y S. Yubero (Coords.), El acoso escolar y su prevención: Perspectivas internacionales (pp. 207-223). Madrid: Biblioteca Nueva.

Zynch, I., Beltrán, M., Ortega, R. \& Llorent, V. (2018). Competencias sociales y emocionales de adolescentes involucrados en diferentes roles de bullying y cyberbullying. Revista de Psicodidáctica,23(2),86-93.

\section{BIOGRAPHICAL NOTES}

\section{LAURA DOMÍNGUEZ DE LA ROSA}

Licenciada en Psicología y Licenciada en Ciencias del Trabajo. Doctora en Ciencias Sociales. Profesora del área de Trabajo Social y Servicios Sociales del Departamento de Piscología Social, Trabajo Social, Antropoloía Social y Estudios de Asia Oriental de la Universidad de Málaga (FEST). Línea de investigación: Fenómenos sociales emergentes tales como nuevas formas de violencia y diversidad familiar. Acreditada a Contratada Doctora.

\section{MARIO MILLÁN-FRANCO}

Graduado en Trabajo Social. Máster en Investigación e Intervención Social y Comunitaria. Doctor. Profesor del área de Trabajo Social y Servicios Sociales del Departamento de Psicología Social, Trabajo Social, Antropología Social y Estudios de Asia Oriental de la Universidad de Málaga (FEST). Acreditado a Contratado Doctor. 